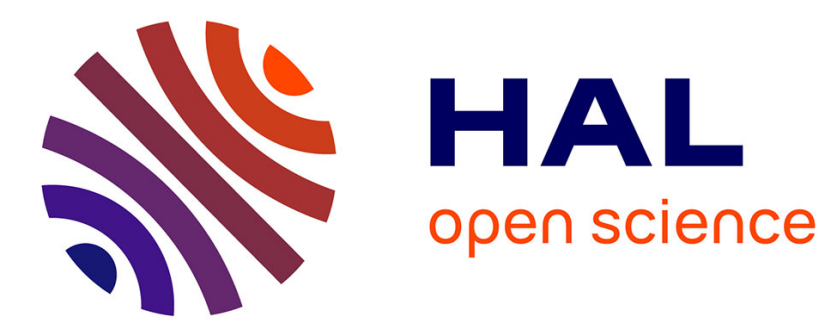

\title{
New insights into two ciprofloxacin-intercalated arrangements for layered double hydroxide carrier materials
}

Nawal Fodil Cherif, Vera Regina Leopoldo Constantino, Oualid Hamdaoui, Fabrice Leroux, Christine Taviot-Guého

\section{To cite this version:}

Nawal Fodil Cherif, Vera Regina Leopoldo Constantino, Oualid Hamdaoui, Fabrice Leroux, Christine Taviot-Guého. New insights into two ciprofloxacin-intercalated arrangements for layered double hydroxide carrier materials. New Journal of Chemistry, 2020, 44 (24), pp.10076-10086. 10.1039/D0NJ00045K . hal-02992475

\section{HAL Id: hal-02992475 \\ https://hal.science/hal-02992475}

Submitted on 23 Nov 2020

HAL is a multi-disciplinary open access archive for the deposit and dissemination of scientific research documents, whether they are published or not. The documents may come from teaching and research institutions in France or abroad, or from public or private research centers.
L'archive ouverte pluridisciplinaire HAL, est destinée au dépôt et à la diffusion de documents scientifiques de niveau recherche, publiés ou non, émanant des établissements d'enseignement et de recherche français ou étrangers, des laboratoires publics ou privés. 


\title{
New insights into two ciprofloxacin-intercalated arrangements for layered double hydroxide carrier materials $\dagger$
}

\author{
Nawal Fodil Cherif, (D) abc Vera Regina Leopoldo Constantino, (iD) \\ Oualid Hamdaoui, (ID) ${ }^{\text {e }}$ Fabrice Leroux (ID) and Christine Taviot-Guého (ID *a
}

\begin{abstract}
This paper describes the intercalation of ciprofloxacin (CIP), a bactericidal antibiotic, into the interlayer space of layered double hydroxides (LDHs). To counter the problem of bacterial resistance and also to improve the properties of the CIP drug, the drug carrier approach promises significant benefits. Through the tight control over the synthesis parameters, particularly the amounts of CIP with respect to aluminum ions, two different $\mathrm{LDH}-\mathrm{CIP}$-intercalated structures were obtained with significantly different interlayer distances, namely, 21 and $32 \AA$. The samples were fully characterized in terms of composition, structure, and morphology. Interestingly, the structure with the largest interlayer distance incorporated both $\mathrm{CIP}$ anions and $\mathrm{Al}(\mathrm{CIP})_{3}$ complex, exhibiting the possibility to increase the CIP drug loading beyond the anionic-exchange capacity of the LDH carrier. In vitro release in a simulated intestinal fluid (phosphate-buffered solution at $\mathrm{pH}$ 7.5) confirmed that LDH was a potentially efficient carrier to deliver CIP in a sustained manner via the anionexchange mechanism. Different release rates were observed depending on the intercalated structure, which were also influenced by the morphological characteristics.
\end{abstract}

\section{Introduction}

In the recent years, a number of studies have addressed the use of organic-inorganic hybrid materials as smart drug carriers to promote the sustained and target-specific delivery of bioactive species in organisms..$^{1-4}$ In this area, layered double hydroxides (LDHs) have attracted considerable attention as host materials for functional species..$^{5-7}$ In particular, a wide variety of pharmaceutical drugs have been intercalated into LDHs, namely, antibiotics, anticancer drugs, vitamins, anticardiovascular agents, diabetes drugs, antifibrinolytic agents, antihypertensives, antimycotic agents, anticoagulants, osteoporosis, antioxidants,

\footnotetext{
${ }^{a}$ Institut de Chimie de Clermont-Ferrand, UMR-CNRS 6296,

Université Clermont Auvergne, Campus des Cézeaux, 24 avenue des Landais, B.P. 800 26, 63171 Aubière, France. E-mail: christine.taviot-gueho@uca.fr

${ }^{b}$ Laboratory of Environmental Engineering, Badji Mokhtar-Annaba University, P.O. Box 12, 23000 Annaba, Algeria

${ }^{c}$ Centre de Recherche Scientifique et Technique en Analyses Physico-Chimiques, B.P. 384, Zone Industrielle Bou-Ismail, Tipaza, Algeria

${ }^{d}$ Instituo de Quimica, Universidade de Sao Paulo, Av. Prof. Lineu Prestes 748 , 05508-000 Sao Paulo, Brazil

${ }^{e}$ Chemical Engineering Department, College of Engineering, King Saud University, P.O. Box 800, Riyadh 11421, Saudi Arabia

$\dagger$ Electronic supplementary information (ESI) available: Includes XRD patterns, TGA-DTG and TGA-MS thermograms, FTIR and FT-Raman spectra, ${ }^{13} \mathrm{C}$ NMR data and fitting of the drug release data with kinetic equations. See DOI: 10.1039/ donjo0045k
}

immunosuppressant corticosteroids, nonsteroidal antiinflammatory drugs, and nucleosides. ${ }^{8,9}$ Intercalated drugs can be released either by deintercalation through anion exchange with the surrounding external anions by mass action law or by the acidic dissolution of LDH layers. When compared with other carrier systems, LDHs are simpler to synthesize in the laboratory, cost-effective, have good biocompatibility, high drug-loading capacity, high drug-transportation efficiency, low toxicity to the target cells or organs, and can offer excellent protection to the loaded molecules from undesired enzymatic degradation. ${ }^{10}$

The present work focuses on the intercalation of ciprofloxacin (CIP), a fluoroquinolone antibiotic, into the interlayer space of LDHs. CIP (4-oxo-7-(1-piperazinyl)-6-fluoro-1-cyclopropyl-1,4dihydroquinoline-3-carboxylic acid) exhibits potent broadspectrum bactericidal activity against most Gram-positive cocci and Gram-negative bacteria, and it is frequently used to treat urinary tract infections, respiratory infections, otitis media treatment, and external ocular infections. ${ }^{11}$ To counter the problem of bacterial resistance and improve the pharmacokinetic and pharmacodynamic properties of CIP drugs, approaches involving nanosized drug carriers promise significant benefits. ${ }^{12,13}$ CIPLoaded polymeric and lipid nanoparticles have, therefore, been described in the recent years. ${ }^{14-17}$ There have also been a few reports in using two-dimensional nanomaterials such as synthetic silicate clays, ${ }^{18-20}$ layered single hydroxides (LSHs), ${ }^{21}$ and LDHs. ${ }^{22-26}$ Most of these works deal with CIP hydrochloride 
salts $\left(\mathrm{CIP}_{\mathrm{HCl}}\right)$, the most commonly used form of CIP in oral and parenteral formulations. Its solubility in water is about two orders of magnitude higher than that of the zwitterionic form $\left(\mathrm{CIP}_{\mathrm{zW}}\right){ }^{27,28}$ These two types of CIP drugs can demonstrate different efficiencies, as shown in the treatment of respiratory infections. ${ }^{29,30}$

Only a few studies have been reported so far on the intercalation/ loading of CIP in LDHs and they have revealed differing results. ${ }^{22-25}$ Hesse et al. performed in vivo tests and concluded that more upstream work is needed on the CIP release from LDH carrier before considering its biomedical applications. ${ }^{23}$ Therefore, the present study aimed to provide a better comprehension of the synthesis of LDH-CIP hybrid materials and their structural features, as well as to identify the key parameters to ultimately produce improved materials. Both CIP hydrochloride salts and CIP zwitterions were used as the reagents to intercalate drugs into $\mathrm{Mg}_{2} \mathrm{Al}$ and $\mathrm{Zn}_{2} \mathrm{Al}$ LDHs by the coprecipitation method. By varying the amounts of CIP with respect to $\mathrm{Al}^{3+}$, an interplay was observed between the precipitation and complexation reactions, leading to two different LDH-CIP-intercalated structures. In order to explain the formation mechanisms, investigate the arrangements of CIP drug confined in LDH interlayer space, and examine the morphology and surface characteristics, a set of complementary techniques were used: chemical elemental analysis (CHNS); inductively coupled plasma atomic emission (ICP-AES); energy-dispersive X-ray (EDX); X-ray powder diffraction (XRD); thermogravimetric analysis (TGA); UV-visible (UV-vis) absorption spectrometry; Fourier-transform infrared (FTIR) and Raman (FT-Raman) spectrometries; solid-state ${ }^{13} \mathrm{C}$ nuclear magnetic resonance $\left({ }^{13} \mathrm{C}\right.$ NMR); scanning (SEM) and high-resolution transmission electron (HRTEM) microscopies; surface area analysis (Brunauer-Emmett-Teller, BET); and zeta potential measurements. A thorough investigation of the XRD data allowed the detailed description of such LDH-CIP assemblies. Finally, the in vitro evaluation of the release performed in simulated intestinal fluid (phosphate-buffered solution (PBS) at $\mathrm{pH}$ 7.5) showed kinetics and release rates depending on the LDH-CIP-intercalated structure, as well as that on the surface characteristics.

\section{Experimental}

\section{Chemicals}

Magnesium nitrate hexahydrate $\left(\mathrm{Mg}\left(\mathrm{NO}_{3}\right)_{2} \cdot 6 \mathrm{H}_{2} \mathrm{O}\right.$, Acros Organics, $98 \%)$, aluminum nitrate nonahydrate $\left(\mathrm{Al}\left(\mathrm{NO}_{3}\right)_{3} \cdot 9 \mathrm{H}_{2} \mathrm{O}\right.$, Acros Organics, $99 \%)$, zinc nitrate hexahydrate $\left(\mathrm{Zn}\left(\mathrm{NO}_{3}\right)_{2} \cdot 6 \mathrm{H}_{2} \mathrm{O}\right.$, Acros Organics, 98\%), sodium hydroxide ( $\mathrm{NaOH}$, Acros Organics, 98\%), acetone $\left(\mathrm{CH}_{3} \mathrm{COCH}_{3}\right.$, VWR Chemicals, $\left.99 \%\right)$, and potassium phosphate monobasic $\left(\mathrm{KH}_{2} \mathrm{PO}_{4}\right.$, Sigma-Aldrich, $\left.99 \%\right)$ were used. $\mathrm{C}_{17} \mathrm{H}_{18} \mathrm{FN}_{3} \mathrm{O}_{3}$ (CIP, 4-oxo-7-(1-piperazinyl)-6-fluoro-1-cyclopropyl1,4-dihydroquinoline-3-carboxylic acid, Sigma-Aldrich, 98\%) and ciprofloxacin hydrochloride monohydrate $\mathrm{C}_{17} \mathrm{H}_{18} \mathrm{FN}_{3} \mathrm{O}_{3} \cdot \mathrm{HCl} \cdot \mathrm{H}_{2} \mathrm{O}$ (Sigma-Aldrich, 99\%), abbreviated as $\mathrm{CIP}_{\mathrm{zw}}$ and $\mathrm{CIP}_{\mathrm{HCl}}$, respectively, were used as received.

\section{Syntheses}

Attempts to intercalate CIP into MgAl and $\mathrm{ZnAl} \mathrm{LDH}$ materials were performed using both anion-exchange and coprecipitation methods. Moreover, two forms of CIP drugs were used: the hydrochloride salt $\mathrm{CIP}_{\mathrm{HCl}}$ and the zwitterionic $\mathrm{CIP}_{\mathrm{zw}}$. CIP molecule possess a carboxylic acid group $\left(\mathrm{p} K_{\mathrm{a} 1}=6.1\right)$ and a piperazine basic group ( $\left.\mathrm{p} K_{\mathrm{a} 2}=8.7\right)$. Therefore, CIP can exist in different ionic states as a function of $\mathrm{pH}$, i.e., cationic at acidic $\mathrm{pH}(\mathrm{pH}<5.0)$, zwitterionic at $\mathrm{pH}$ encompassing the $\mathrm{p} K_{\mathrm{a}}(6.0<\mathrm{pH}<8.5)$, and anionic at basic $\mathrm{pH}(\mathrm{pH}>9.2) .{ }^{31-33}$ To obtain CIP in its anionic form, $\mathrm{CIP}_{\mathrm{HCl}}$ and $\mathrm{CIP}_{\mathrm{zw}}$ were dissolved in ultrapure Milli-Q water at $\mathrm{pH} 10.7$ by the slow addition of $0.1 \mathrm{~mol} \mathrm{~L}^{-1} \mathrm{NaOH}$.

Preparation of $\mathrm{LDH}-\mathrm{NO}_{3}$ precursors. $\mathrm{Mg}_{2} \mathrm{Al}-\mathrm{NO}_{3}$ and $\mathrm{Zn}_{2} \mathrm{Al}-\mathrm{NO}_{3}$ LDH having a $\mathrm{M}^{2+} / \mathrm{Al}^{3+}$ molar ratio of $2\left(\mathrm{M}^{2+}: \mathrm{Mg}^{2+}\right.$ or $\left.\mathrm{M}^{2+}: \mathrm{Zn}^{2+}\right)$ intercalated with nitrate anions were prepared by $\mathrm{NaOH}$-induced coprecipitation from solutions containing $\mathrm{Mg}\left(\mathrm{NO}_{3}\right)_{2} \cdot 6 \mathrm{H}_{2} \mathrm{O}$ / $\mathrm{Al}\left(\mathrm{NO}_{3}\right)_{3} \cdot 9 \mathrm{H}_{2} \mathrm{O}$ or $\mathrm{Zn}\left(\mathrm{NO}_{3}\right)_{2} \cdot 6 \mathrm{H}_{2} \mathrm{O} / \mathrm{Al}\left(\mathrm{NO}_{3}\right)_{3} \cdot 9 \mathrm{H}_{2} \mathrm{O}$. The $\mathrm{pH}$ value was fixed to 9 for $\mathrm{Mg}_{2} \mathrm{Al}-\mathrm{NO}_{3}$ and 7 for $\mathrm{Zn}_{2} \mathrm{Al}_{-}-\mathrm{NO}_{3}$. After an ageing step of $24 \mathrm{~h}$ under a $\mathrm{N}_{2}$ atmosphere at room temperature, the precipitates were washed with deionized water and dried at $40{ }^{\circ} \mathrm{C}$ in air.

Anion-exchange intercalation procedure. Approximately $50 \mathrm{mg}$ of finely ground $\mathrm{LDH}-\mathrm{NO}_{3}$ precursors were dispersed into $50 \mathrm{~mL}$ water containing different excesses of CIP as compared to the LDH anion-exchange capacity ( 5 times molar excess at 2.0 and 1.0). The experiments were carried out under a $\mathrm{N}_{2}$ atmosphere at room temperature. The $\mathrm{pH}$ of the exchange medium was adjusted to 10.5 by the slow addition of $0.1 \mathrm{~mol} \mathrm{~L}^{-1} \mathrm{NaOH}$. The mixtures were stirred for $24 \mathrm{~h}$. The resultant products were collected by thoroughly washing the precipitates with deionized water/acetone and were dried at $40{ }^{\circ} \mathrm{C}$ in air.

Coprecipitation intercalation procedure. Here, $20 \mathrm{~mL}$ aqueous solutions containing $2 \mathrm{mmol} \mathrm{M}^{2+}\left(\mathrm{NO}_{3}\right)_{2} \cdot 6 \mathrm{H}_{2} \mathrm{O}$ and $1 \mathrm{mmol}$ $\mathrm{Al}\left(\mathrm{NO}_{3}\right)_{3} \cdot 9 \mathrm{H}_{2} \mathrm{O}$, leading to a $\mathrm{M}^{2+} / \mathrm{Al}^{3+}$ molar ratio equal to 2 , were added dropwise $\left(0.11 \mathrm{~mL} \mathrm{~min}{ }^{-1}\right)$ using peristaltic pumps to a stirred reactor vessel containing $100 \mathrm{~mL}$ CIP solutions in 2 different concentrations as compared to the amount of $\mathrm{Al}^{3+}$ $(\mathrm{CIP} / \mathrm{Al}=0.5$ and $\mathrm{CIP} / \mathrm{Al}=1.0)$. With $\mathrm{CIP}_{\mathrm{zw}}$, due to its low solubility, ${ }^{28}$ the syntheses were performed only for $\mathrm{CIP} / \mathrm{Al}=0.5$. The $\mathrm{pH}$ value was maintained constant during the reaction at a value of 10.5 by the simultaneous addition of $0.5 \mathrm{~mol} \mathrm{~L}^{-1} \mathrm{NaOH}$ solution. The resulting slurry was aged for $24 \mathrm{~h}$ at room temperature. The solids recovered by centrifugation were washed 3 times with deionized water and dried in air at $40{ }^{\circ} \mathrm{C}$. These samples were denoted as $\quad \mathrm{M}^{2+}{ }_{2} \mathrm{Al}-\mathrm{CIP} \mathrm{HCl}_{\mathrm{HC}} 0.5, \quad \mathrm{M}^{2+}{ }_{2} \mathrm{Al}-\mathrm{CIP} \mathrm{HC} @ 1.0$, and $\mathrm{M}^{2+}{ }_{2} \mathrm{Al}-$ $\mathrm{CIP}_{\text {zw@0.5, }}$, where the "@0.5/1.0" notation referred to the CIP/Al ratio.

\section{Elemental analysis}

The percentages of carbon, nitrogen, and hydrogen in the hybrids were determined using a Flash 2000 CHNS elemental analyzer from Thermo Fisher Scientific. The metal contents of the samples were measured by an ICP-AES instrument from Jobin Yvon Horiba ULTIMA C and by SEM with EDX performed on a field-emission scanning electron microscope, namely, Zeiss SUPRA 55VP. For the ICP-AES analysis, approximatively 
$5 \mathrm{mg}$ of the samples were dissolved in $5 \mathrm{~mL}$ concentrated nitric acid before dilution and measurement. For the SEM-EDX analysis, the samples were deposited on double-sided tapes and then Au was metalized by sputtering in a vacuum. TGA was conducted using a PerkinElmer TGA7 apparatus. Powdered samples $(\sim 20 \mathrm{mg})$ were placed in alumina open pans. The temperature was scanned at $5{ }^{\circ} \mathrm{C} \mathrm{min}^{-1}$ from 25 to $800{ }^{\circ} \mathrm{C}$ under an air atmosphere. Mass-coupled thermal analysis (TGA-DSC-MS) was performed using a Netzsch TGA/DSC 490 PC Luxx thermal analyzer coupled to an $403 \mathrm{C}$ Aëolos mass spectrometer at the heating rate of $5{ }^{\circ} \mathrm{C} \mathrm{min}{ }^{-1}$ under an air atmosphere (air flow: $50 \mathrm{~mL} \mathrm{~min}^{-1}$ ).

\section{Structural and morphological characterizations}

XRD patterns were recorded using a Philips X'Pert Pro diffractometer equipped with an X'Celerator detector that used $\mathrm{Cu}-\mathrm{K} \alpha_{1,2}$ radiation. The instrument was used in the $\theta-\theta$ reflection mode, fitted with a nickel filter, 0.04 rad Soller slits, $10 \mathrm{~mm}$ mask, $1 / 2^{\circ}$ fixed divergence slit, and $1 / 4^{\circ}$ fixed antiscatter slit. The XRD data were measured over a $2 \theta$ range of $2-80^{\circ}$ with a step size of $0.0167^{\circ}$ and a total counting time of about $3 \mathrm{~h}$. The Le Bail method comprising the full-pattern decomposition of the XRD pattern of the powdered sample was used to determine the cell parameters of $\mathrm{Zn}_{2} \mathrm{Al}-\mathrm{CIP}_{\mathrm{HC1} @ 1.0}$ assuming the $R \overline{3} m$ space group, which is typical for LDH materials, and to determine the intensities of the diffraction peaks. The refinement was carried out using the FullProf software. ${ }^{34}$ The pseudo-Voigt Thompson, Cox, and Hastings profile functions were selected to analyze the peak profiles. ${ }^{35}$ The onedimensional electron density distribution along the $c$-stacking axis was calculated for $\mathrm{Zn}_{2} \mathrm{Al}-\mathrm{CIP} \mathrm{HCl}_{\mathrm{H} 1.0}$ from the intensity of the 00 diffraction lines according to the following equation (in the case of centrosymmetric structures):

$$
\rho(z)=\frac{2}{L_{z}} \sum_{l} F_{00 l} \cdot\left(\frac{\cos 2 \pi l}{c}\right) \cdot \cos \varphi_{00 l}
$$

where $c$ is the unit cell parameter, $z$ is the fractional coordinate along the $c$-stacking axis, $F_{00 l}$ are the structure factors, and $\phi_{00 l}$ is the "phase" of the $00 l$ reflection equal to $0^{\circ}$ or $180^{\circ} .^{36}$ Here, 11 isolated $00 l$ diffraction lines were used for calculating the $1 \mathrm{D}$ plots. The signs of the structure factors, i.e., the phases, were obtained from the scattering contributions of the hydroxide layers by assuming a relatively small contribution of the intercalated molecules. The Patterson map for $\mathrm{Zn}_{2} \mathrm{Al}-\mathrm{CIP}_{\mathrm{HCl}} @ 1.0$ was calculated using the GFourier program ${ }^{37}$ by employing the observed structure factors, $F_{\mathrm{obs}}$, extracted from the Le Bail whole-powder diffraction pattern decomposition and plotted in the form of contour plots summed from 0 to 1 along the $a / b$-axis.

The UV-vis spectra were recorded on a Shimadzu UV-2600 spectrometer equipped with an integrating sphere attachment. A suspension of LDH-CIP materials $\left(10 \mathrm{mg} \mathrm{mL}^{-1}\right)$ was stirred for $2 \mathrm{~h}$, dropped on a high-quality glass substrate, and allowed to dry at $50{ }^{\circ} \mathrm{C}$ for $2 \mathrm{~h}$. The resulting solid thin films were measured in the transmittance mode in the range of $200-800 \mathrm{~nm}$. The FTIR spectra were obtained with a Nicolet 5700 spectrometer in the range of $400-4000 \mathrm{~cm}^{-1}$ at an average of 64 scans at a resolution of $8 \mathrm{~cm}^{-1}$ and using the $\mathrm{KBr}$ pellet method with approximately $1 \%$ weight of the samples. FT-Raman spectra were recorded from 200 to $3500 \mathrm{~cm}^{-1}$ at room temperature using a FT-Raman spectrometer (Bruker FRS-100/S) at an excitation wavelength of $1064 \mathrm{~nm}$ (Nd:YAG laser, Coherent Compass 1064$500 \mathrm{~N}$ ), laser power of $80 \mathrm{~mW}$, Ge detector, spectral resolution of $4 \mathrm{~cm}^{-1}$, and 256 scans. The ${ }^{13} \mathrm{C}$ solid-state NMR experiments were performed on a 300 Bruker Advance spectrometer operating at $75.47 \mathrm{MHz}$ at room temperature. The experiments were carried out under the magic-angle spinning (MAS) condition at $10 \mathrm{kHz}$ and $4 \mathrm{~mm}$-diameter zirconia rotor. The ${ }^{13} \mathrm{C}$ spectra were obtained by using the proton-enhanced cross-polarization method (CP; contact time of $1 \mathrm{~ms}$ and recycling time of $5 \mathrm{~s}$ ) and are referenced to the carbonyl of glycine calibrated at $176.03 \mathrm{ppm}$. Data were phased using the TOPSPIN software.

The HRTEM images were acquired using a JEOL $2100 \mathrm{~F}$ microscope operating at an accelerating voltage of $200 \mathrm{kV}$. The samples were dispersed in water and subject to ultrasonic treatment for $5 \mathrm{~min}$. Then, a drop of the suspension was deposited on a 150 mesh Formvar carbon-coated copper grid and dried at room temperature.

The surface area measurements were performed using the BET method. $\mathrm{N}_{2}$ adsorption/desorption isotherms were collected using a Micromeritics ASAP2020 analyzer at $-196{ }^{\circ} \mathrm{C}$. Prior to the measurements, the samples were degassed at $80^{\circ} \mathrm{C}$ for $12 \mathrm{~h}$. Photon correlation spectroscopy was conducted to record the zeta potential of the dilute suspensions of powders using a Malvern Nanosizer Nano ZS instrument.

\section{Drug release experiments}

An accurately weighted amount of $\mathrm{Zn}_{2} \mathrm{Al} @ \mathrm{CIP}$ (around $30 \mathrm{mg}$ ) was dispersed in $250 \mathrm{~mL}$ PBS ( $\mathrm{pH}$ 7.5) release medium simulating the intestinal fluid. The drug release experiments, in duplicate, were performed at $25{ }^{\circ} \mathrm{C}$ under constant stirring (200 rpm) and under sink conditions, i.e., with maximum CIP concentrations that were very low as compared to its saturation solubility at $\mathrm{pH} 7.5 .^{38}$ At defined time intervals, $3 \mathrm{~mL}$ of the release medium was withdrawn, filtered, and replaced with an equivalent amount of fresh PBS. The amount of the released CIP was determined by UV-vis absorption (Shimadzu UV-2600) at $\lambda=271 \mathrm{~nm}$. The dependence of the absorbance on the concentration was linear in the investigated range between $1 \times 10^{-3}$ and $1 \times 10^{-4} \mathrm{mg} \mathrm{mL}^{-1}$. Higuchi and Korsmeyer-Peppas diffusion kinetic models were employed to fit the drug release behavior of $\mathrm{Zn}_{2} \mathrm{Al} @ \mathrm{CIP}$ nanohybrids in PBS. ${ }^{39}$

\section{Results}

\section{Synthesis and characterization of LDH-CIP nanohybrids}

The intercalation of CIP into $\mathrm{Zn}_{2} \mathrm{Al}$ and $\mathrm{Mg}_{2} \mathrm{Al}$ LDH was investigated using the anion-exchange and coprecipitation methods, starting from different $\mathrm{CIP} / \mathrm{Al}$ molar ratios $(0.5,1.0,2.0$, and 5.0) and using two forms of CIP drugs, i.e., the hydrochloride salt $\left(\mathrm{CIP}_{\mathrm{HCl}}\right)$ and the zwitterionic form $\left(\mathrm{CIP}_{\mathrm{zw}}\right)$. The $\mathrm{pH}$ applied for all the synthesis tests around 10.5 corresponds to the anionic form of CIP suitable for its intercalation into the LDH host. 
It should be noted that the solubility of $\mathrm{CIP}_{\mathrm{zw}}$ in water $\left(0.067 \mathrm{mg} \mathrm{mL}^{-1}\right.$ at neutral $\mathrm{pH}^{28}$ and approximately $2 \mathrm{mg} \mathrm{mL}^{-1}$ at $\mathrm{pH} 10.5)$ is much lower than that of $\mathrm{CIP}_{\mathrm{HCl}}\left(30 \mathrm{mg} \mathrm{mL}^{-1}\right.$ at neutral $\mathrm{pH}){ }^{27}$ then, synthesis with $\mathrm{CIP}_{\mathrm{zw}}$ was attempted only for $\mathrm{CIP} / \mathrm{Al}=0.5$.

The first important result in this study is that all our attempts to prepare the materials through the anion-exchange method starting from nitrate or chloride precursors failed. As evidenced by the XRD analysis (Fig. ESI1, ESI†), either the exchange did not take place (yielding an XRD pattern similar to the LDH precursor) or the decomposition/dissolution of LDH layers was observed with the disappearance of the 110/113 characteristic double peak. On the other hand, using the coprecipitation method, the intercalation of CIP was obtained but only for CIP/Al molar ratios lower than or equal to 1 , which implied sub-excess conditions as compared to the intercalation capacity of LDH. Moreover, depending on the CIP/Al molar ratio of 1.0 or $0.5,2$ different interlayer distances were observed.

For $\mathrm{CIP} / \mathrm{Al}=0.5$, with $\mathrm{CIP}_{\mathrm{zw}}$ and $\mathrm{CIP}_{\mathrm{HCl}}$, the XRD data (Fig. 1A) reveal very similar diffraction patterns with a similar shift in the $00 l$ diffraction peaks to low $2 \theta$ angles (as compared to the nitrate LDH precursors, Fig. ESI2, ESI $\dagger$ ), which are

(a) $C I P I A I=0.5$
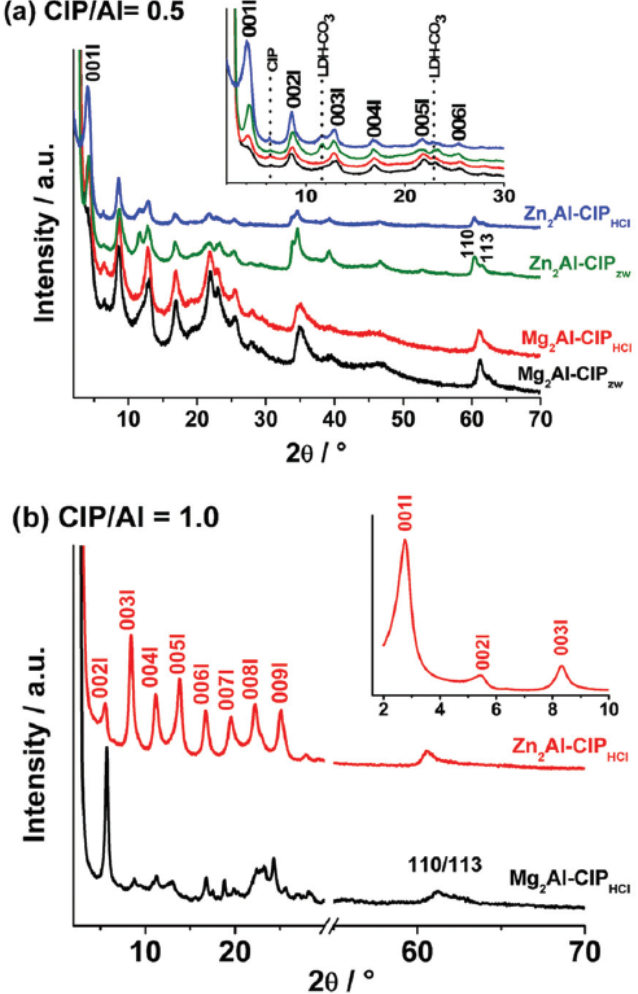

Fig. 1 PXRD patterns of $\mathrm{Zn}_{2} \mathrm{Al}-\mathrm{CIP}$ and $\mathrm{Mg}_{2} \mathrm{Al}-\mathrm{CIP}$ samples obtained by coprecipitation at (a) $\mathrm{CIP} / \mathrm{Al}=0.5$ and $(\mathrm{b}) \mathrm{CIP}_{\mathrm{HCl}} / \mathrm{Al}=1.0$. Insets show the $00 l$ diffraction peaks at low $2 \theta$; the vertical dashed lines denote the presence of $\mathrm{LDH}-\mathrm{CO}_{3}$ and free CIP impurities. The entire diagram for (b) is shown in Fig. ESI4 (ESI†). consistent with the enlargement of the interlayer distance $d$. Often, with LDH systems, the $\mathrm{Zn}_{2} \mathrm{Al}$ LDH host composition leads to better crystallinity than its $\mathrm{Mg}_{2} \mathrm{Al}$ counterpart. The observation of the $110 / 113$ double peak at $2 \theta=\sim 62^{\circ}$ confirms the formation of LDH layers. The $d$-spacing values estimated from the position of the first $001 l$ diffraction line are about $20.8 \AA$ for $\mathrm{Zn}_{2} \mathrm{Al}-\mathrm{CIP}_{\mathrm{zw} @ 0.5}, 21.2 \AA$ for $\mathrm{Zn}_{2} \mathrm{Al}-\mathrm{CIP} \mathrm{HCl}_{\mathrm{HC} .5}, 23.3 \AA$ for $\mathrm{Mg}_{2} \mathrm{Al}-\mathrm{CIP}_{\mathrm{zw} 0.5}$, and $21.5 \AA$ for $\mathrm{Mg}_{2} \mathrm{Al}-\mathrm{CIP}_{\mathrm{HCl} @ 0.5}$. In all the samples, additional peaks can be observed, particularly at $2 \theta=11.6^{\circ}(7.6 \AA)$ and $2 \theta=22.9^{\circ}(3.8 \AA)$, indicating the presence of $\mathrm{LDH}-\mathrm{CO}_{3}$, which was predictable given the low excess of CIP used. In fact, $\mathrm{LDH}-\mathrm{NO}_{3}$ was certainly formed first and turned entirely or partly into $\mathrm{LDH}-\mathrm{CO}_{3}$ during the washing and drying processes; further, it was in contact with $\mathrm{CO}_{2}$ gas from the ambient atmosphere ${ }^{40}$ Furthermore, the peak observed at $2 \theta=6.3^{\circ}(14 \AA)$ may be attributed to the residual free CIP (Fig. ESI3, ESI $\dagger$ ). ${ }^{41}$

For $\mathrm{CIP} / \mathrm{Al}=1.0$, with the $\mathrm{Zn}_{2} \mathrm{Al}$ LDH host, an important expansion of the interlayer space was observed on the XRD pattern (Fig. 1B), leading to an interlayer distance of around $32.0 \AA$ A. Up to $1100 l$ diffraction lines are visible for $\mathrm{Zn}_{2} \mathrm{Al}_{-\mathrm{CIP}} \mathrm{HCl} 101.0$, suggesting a rather well-ordered packing in the interlayer space. In contrast, much lower crystallinity was observed with the $\mathrm{Mg}_{2} \mathrm{Al}$ host and there is no clear evidence of CIP intercalation. The first intense peak located at $2 \theta=6.3^{\circ}$ (about $14 \AA$ ) on the XRD pattern can be probably attributed to the CIP salt.

As the first approach, the gallery heights can be calculated by subtracting the value of the hydroxide layer thickness $(\sim 2.1 \AA)$ as well as the hydrogen bonding distance $(\sim 2.7 \AA)^{43}$ from the observed $d$-spacing values. This leads to values ranging from 13.3 to $15.8 \AA$ for the series of samples prepared at $\mathrm{CIP} / \mathrm{Al}=0.5$; when compared with the length of the molecule (11.3 Å, Fig. 2), the formation of a monolayer and interdigitated arrangement can be assumed. A slight variation in the interlayer water content can explain the different interlayer distances. On the other hand, for $\mathrm{Zn}_{2} \mathrm{Al}-\mathrm{CIP} \mathrm{HCl}_{\mathrm{H} 1.0}$, a much larger gallery height is obtained, i.e., $24.5 \AA$, indicating the formation of a double layer without interdigitation.

The relatively high crystallinity of the $\mathrm{Zn}_{2} \mathrm{Al}-\mathrm{CIP}_{\mathrm{HCl}} @ 1.0$ sample, as well as the absence of impurities, allowed us to obtain the entire diffraction pattern profile refinement. Our data are consistent with the $R \overline{3} m$ space group (Fig. 3), which is often reported for LDH materials. ${ }^{43}$ An interlayer distance of $d=32.15 \AA$ is deduced from

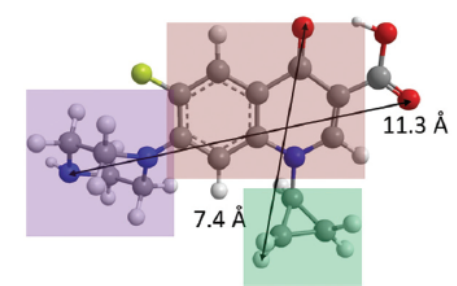

Fig. 2 Molecular structure of the CIP drug molecule extracted from the crystal structure of the hydrochloride 1.34 -hydrate. ${ }^{42}$ Quinolone, piperazine, and cyclopropane rings are highlighted in pink, purple and green colors, respectively. 


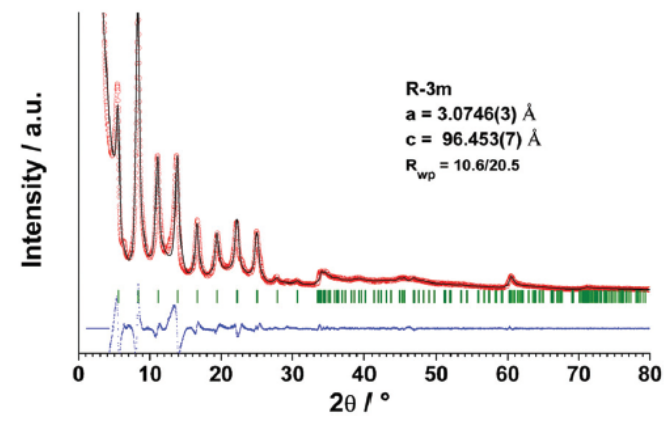

Fig. 3 Profile analysis of the XRD pattern of $\mathrm{Zn}_{2} \mathrm{Al}-\mathrm{CIP}_{\mathrm{HCl}} \mathrm{A1.0}$ : experi mental X-ray diffraction (circles), calculated (line), Bragg reflections (ticks) and difference profiles. Refinement in a hexagonal cell with the $R \overline{3} \mathrm{~m}$ space group. $R_{\mathrm{wp}}$ denotes the reliability factor

the value of the $c$ parameter of the hexagonal cell; $c=96.453$ (7) $\AA=$ $3 \times d$. Moreover, the value obtained for the cell parameter $a=3.0746$ (3) $\AA$ indicates a $\mathrm{Zn} / \mathrm{Al}$ molar ratio of $2.57,{ }^{44}$ which is higher than that applied during the synthesis process, namely, 2 . This is not surprising considering the high value of $\mathrm{pH}$ (10.5) during synthesis. Indeed, above a $\mathrm{pH}$ of $9, \mathrm{Al}$ can enter back into the solution as soluble aluminate ions, i.e., $\mathrm{Al}(\mathrm{OH})_{4}{ }^{-}$, thereby leading to an increase in the $\mathrm{Zn} / \mathrm{Al}$ ratio. ${ }^{45}$ Secondly, the preparation of hybrid LDHs by the coprecipitation method should be viewed as a self-assembly process with the possible adjustment of the composition/charge density of the hydroxide layer for better accommodation of the interlayer species. ${ }^{46}$

The HRTEM images (Fig. 4) show the well-developed layered structures, and the different distances can be estimated between the parallel fringes, namely, $\sim 28 \AA$ for $\mathrm{Zn}_{2} \mathrm{Al}-\mathrm{CIP}_{\mathrm{HCl}}{ }_{1.0}$ and $19 \AA$ for $\mathrm{Zn}_{2} \mathrm{Al}_{-\mathrm{CIP}} \mathrm{HCl@0.5}_{3}$, which are close to the $d$-spacing values determined by XRD, confirming the existence of these two intercalated structures.

Owing to the better crystallinity observed for the ZnAl-LDH system, only these phases will be considered in the following discussion. The chemical compositions listed in Table 1 were obtained by combining the CHNS, ICP, EDX, and TGA data. Marginal differences are observed in the $\mathrm{Zn} / \mathrm{Al}$ molar ratios between the ICP analysis of the bulk and the EDX analysis

(a)

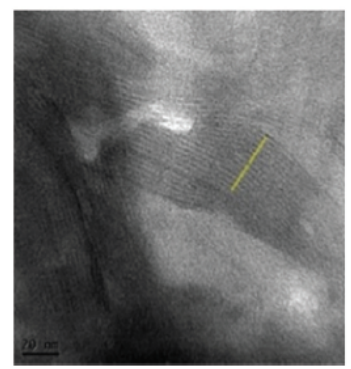

Fig. 4 HRTEM images of (a) $\mathrm{Zn}_{2} \mathrm{Al}-\mathrm{CIP}_{\text {HCla1.0 }}$ (scale bar: $20 \mathrm{~nm}$ ) (b) and $\mathrm{Zn}_{2} \mathrm{Al}-\mathrm{CIP}$ HClaO.5 (scale bar: $10 \mathrm{~nm}$ ). of the crystals in the case of the $\mathrm{Zn}_{2} \mathrm{Al}-\mathrm{CIP} \mathrm{zw}_{\mathrm{zw} 0.5}$ and $\mathrm{Zn}_{2} \mathrm{Al}$ $\mathrm{CIP}_{\mathrm{HCl}(0.5}$ samples, indicating certain heterogeneity for these samples related to the presence of $\mathrm{Zn}_{2} \mathrm{Al}-\mathrm{CO}_{3} / \mathrm{NO}_{3}$ impurities, as evidenced by the XRD data. For expressing the chemical formula of the $\mathrm{Zn}_{2} \mathrm{Al}-\mathrm{CIP}_{\mathrm{zw} @ 0.5}$ and $\mathrm{Zn}_{2} \mathrm{Al}-\mathrm{CIP} \mathrm{HCl} @ 0.5$ samples, the average $\mathrm{Zn} / \mathrm{Al}$ ratio of 2.15 was assumed, as determined by the ICP analyses. The CHNS analysis was used to calculate the amount of intercalated CIP, also considering the presence of $\mathrm{NO}_{3}{ }^{-}$and $\mathrm{CO}_{3}{ }^{2-}$ ions, as well as the residual free CIP as shown in the XRD data. A relatively good agreement was obtained between the calculated and experimental values with the compositions of the mixtures, as listed in Table 1.

On the other hand, for $\mathrm{Zn}_{2} \mathrm{Al}-\mathrm{CIP}_{\mathrm{HCl}} @ 1.0$, the EDX values were repeatable and similar to the ICP results, confirming the purity of this sample with $\mathrm{Zn} / \mathrm{Al}=2.15$. Interestingly, this value is much lower than that deduced from the XRD analysis from the refinement of the cell parameter $a$, namely, 2.57. Since the value of the cell parameter $a$ relates only to the composition of the hydroxide layers, this discrepancy indicates the presence of additional $\mathrm{Al}^{3+}$ ions probably located in the interlayer space. Furthermore, the CHNS analysis reveals an important amount of carbon, larger than those measured in the $\mathrm{Zn}_{2} \mathrm{Al}-\mathrm{CIP}_{\mathrm{zw} / \mathrm{HCl} 0.5}$ samples and also larger than the amount of CIP needed to compensate the positive charge of the LDH layers. Therefore, we could confirm the cointercalation of CIP anions and $\mathrm{Al}^{3+}$ cations. One part of CIP compensates the charges of the LDH layer and the other part, i.e., the excess, is associated to the presence of $\mathrm{Al}^{3+}$ cations. Hence, the following chemical formula is proposed for $\mathrm{Zn}_{2} \mathrm{Al}-\mathrm{CIP} \mathrm{HCl}_{\mathrm{HC1.0}}: \mathrm{Zn}_{2.14} \mathrm{Al}_{0.86}(\mathrm{OH})_{6}(\mathrm{CIP})_{0.86}\left(\mathrm{CIP}_{2.9} \mathrm{Al}\right)_{0.14} \cdot 8.0 \mathrm{H}_{2} \mathrm{O}$.

Similar TGA curves are observed for the $\mathrm{Zn}_{2} \mathrm{Al}-\mathrm{CIP}_{\mathrm{zw} @ 0.5}$ and $\mathrm{Zn}_{2} \mathrm{Al}-\mathrm{CIP}_{\mathrm{HCl} 0.5}$ samples (Fig. ESI5, ESI $\dagger$ ) that are both intercalated with anionic CIP that start decomposing at $300{ }^{\circ} \mathrm{C}$, similar to that observed in both the CIP salts. ${ }^{47}$ On the other hand, the thermal profile of the $\mathrm{Zn}_{2} \mathrm{Al}-\mathrm{CIP}_{\mathrm{zw} / \mathrm{HCl} @ 0.5}$ samples are very different from that obtained for $\mathrm{Zn}_{2} \mathrm{Al}-\mathrm{CIP}_{\mathrm{HCl} @ 1.0}$ in the 250-500 ${ }^{\circ} \mathrm{C}$ range, indicating the influence of the drug arrangement between the layers in the decomposition processes. TG-MS analysis results of the $\mathrm{Zn}_{2} \mathrm{Al}-\mathrm{CIP}_{\mathrm{HCl} \text { 1.0 }}$ sample (Fig. ESI6, ESI $\dagger$ ) show pertinent weight loss above $450{ }^{\circ} \mathrm{C}$, which can be attributed to the release of $\mathrm{CO}_{2}$ in large amounts due to the high content of intercalated CIP. If we consider that fluoride remains and forms metal fluoride residues, the total weight losses observed by TGA are consistent with the chemical formulas of the samples, as shown in Table 1. As reported for the thermal decomposition of the metal complexes with CIP, ${ }^{48}$ metal cations from the LDH layers could combine with CIP, probably leading to the formation of metal oxides or fluoride residues.

In the range of $1700-1300 \mathrm{~cm}^{-1}$, the FTIR spectra of all the CIP-intercalated LDH samples (Fig. ESI7, ESI $\dagger$ ) are rather similar to the reported spectrum of the CIP solution at $\mathrm{pH} 9^{49}$ with the main bands at 1628, 1580, 1385, and $1360 \mathrm{~cm}^{-1}$, confirming the intercalation of the CIP drug in the anionic form regardless of the salt and $\mathrm{CIP} / \mathrm{Al}$ ratio. The band assigned to the $\nu_{\text {as }} \mathrm{COO}^{-}$vibrational mode is observed as a shoulder at about $1580 \mathrm{~cm}^{-1}$, but that related to $\nu_{\mathrm{s}} \mathrm{COO}^{-}$overlaps with the bands of nitrate anions $\left(\nu_{3} \mathrm{NO}_{3}\right)$ at $1384 \mathrm{~cm}^{-1}$ and carbonate anions 
Table 1 Chemical analysis and proposed formulae for CIP-intercalated samples

\begin{tabular}{|c|c|c|c|c|c|c|}
\hline \multirow[b]{2}{*}{$\mathrm{Zn}_{2} \mathrm{Al}$-samples } & $\mathrm{C}^{a, b}$ & $\mathbf{N}^{a, b}$ & $\mathrm{H}^{a, b}$ & \multirow[b]{2}{*}{$\mathrm{Zn} / \mathrm{Al}$ molar ratio $^{b} \mathrm{ICP} / \mathrm{EDX}$} & \multirow{2}{*}{$\frac{\text { Total weight loss }{ }^{c, d}}{(\mathrm{wt} \%)}$} & \multirow[t]{2}{*}{$\underline{\text { Drug loading }}^{e}$} \\
\hline & \multicolumn{3}{|l|}{$(w t \%)$} & & & \\
\hline $\mathrm{CIP}_{\mathrm{zw} @ 0.5}$ & $22.01(22.08)$ & $5.04(5.04)$ & $3.63(3.63)$ & $2.10 / 2.1-2.6(2.05)$ & $57.5(60.4)$ & $41.7 \pm 1.0$ \\
\hline \multicolumn{7}{|c|}{$66 \% \mathrm{Zn}_{2.0} \mathrm{Al}_{1.0}(\mathrm{OH})_{6}(\mathrm{CIP})_{1.0} 3.5 \mathrm{H}_{2} \mathrm{O}+11 \% \mathrm{Zn}_{2.0} \mathrm{Al}_{1.0}(\mathrm{OH})_{6}\left(\mathrm{NO}_{3}\right)_{1.0} 3.0 \mathrm{H}_{2} \mathrm{O}+19.5 \% \mathrm{Zn}_{2.2} \mathrm{Al}_{0.8}(\mathrm{OH})_{6}\left(\mathrm{CO}_{3}\right)_{0.4} 2.0 \mathrm{H}_{2} \mathrm{O}+3.5 \% \mathrm{CIP}$} \\
\hline $\begin{array}{l}\mathrm{CIP}_{\mathrm{HCl} @ 1.0} \\
\mathrm{Zn}_{2.14} \mathrm{Al}_{0.86}(\mathrm{OH})\end{array}$ & $\begin{array}{c}31.00(31.00) \\
\mathrm{CIP})_{0.86} \mathrm{CIP}_{0.41} \mathrm{Al}\end{array}$ & $\begin{array}{l}6.40(6.40) \\
8.0 \mathrm{H}_{2} \mathrm{O}\end{array}$ & $4.39(4.39)$ & $2.15 / 2.2-2.3(2.15)$ & $67.60(71.30)$ & $50.3 \pm 0.5$ \\
\hline
\end{tabular}

$\mathrm{Zn}_{2.14} \mathrm{Al}_{0.86}(\mathrm{OH})_{6}(\mathrm{CIP})_{0.86} \mathrm{CIP}_{0.41} \mathrm{Al}_{0.14} \cdot 8.0 \mathrm{H}_{2} \mathrm{O}$

${ }^{a} \mathrm{CHN} \pm 0.05 \mathrm{wt} \% .{ }^{b}$ Values in the brackets are deduced from the proposed formulae. ${ }^{c}$ TGA analysis \pm 0.01 wt $\% .{ }^{d}$ Values in the brackets are calculated assuming that the fluoride remain. ${ }^{e} \mathrm{CIP}$ loading calculated considering the total amount of CIP, i.e., intercalated and free CIP.

$\left(\nu_{3} \mathrm{CO}_{3}\right)$ at $1360 \mathrm{~cm}^{-1}$ from $\mathrm{LDH}-\mathrm{NO}_{3}$ and $\mathrm{LDH}-\mathrm{CO}_{3}$ impurities, respectively. As a consequence, we could not identify the type of interaction between the carboxylate function and LDH layers based on the separation of bands, i.e., $\Delta \nu=\nu_{\mathrm{as}} \mathrm{COO}^{-}-\nu_{\mathrm{s}} \mathrm{COO}^{-}$, as proposed elsewhere..$^{50}$ By comparing the relative intensity of the bands at 1620 and $1384 \mathrm{~cm}^{-1}\left(I_{1620} / I_{1384}\right),{ }^{50}$ a lower intensity ratio can be obtained for $\mathrm{Zn}_{2} \mathrm{Al}-\mathrm{CIP}_{\mathrm{Zw} @ 0.5}$ as compared to that for $\mathrm{Zn}_{2} \mathrm{Al}-\mathrm{CIP} \mathrm{HCl}_{\mathrm{H} 0.5}$, indicating a higher amount of nitrate anion in the former case. This corroborates the compositions proposed for these materials, as listed in Table 1. In the FT-Raman spectra (Fig. ESI8, ESI $\dagger$ ), the region between 1480 and $1440 \mathrm{~cm}^{-1}$ is related to the hydrogen deformation modes of the piperazine group and undergoes modifications whether the nitrogen atom is protonated or not. ${ }^{51}$ The modifications observed in this spectral region for LDH-CIP materials are very similar to those reported in the literature for CIP at $\mathrm{pH} 11$ in an aqueous solution, ${ }^{49}$ indicating that the terminal nitrogen of the piperazine group is not protonated in LDH-CIP materials.

The solid-state CP MAS ${ }^{13} \mathrm{C}$ NMR spectra of the LDH-CIP materials and CIP salts are shown in Fig. 5. The assignment of the chemical shifts (Table ESI1, ESI $\dagger$ ) was done by referring to the NMR characterization of the $\mathrm{CIP}_{\mathrm{zw}}$ salt ${ }^{52}$ and the aluminum complexes of CIP reported by Chattah et al. ${ }^{53}$ The signals in the ${ }^{13} \mathrm{C}$ NMR spectrum of CIP can be classified into three groups corresponding to the three main components of the drug, namely, quinolone moiety (C4, C3a), piperazine ring $\left(\mathrm{C}^{\prime} 6^{\prime} 3^{\prime} 5^{\prime}\right)$, and cyclopropane ring (C1a and $\mathrm{C} 1 \mathrm{~b})$. One interesting difference between $\mathrm{CIP}_{\mathrm{HCl}}$ and $\mathrm{CIP}_{\mathrm{zW}}$ is with respect to $\mathrm{C} 3 \mathrm{a}$, which appears at $168 \mathrm{ppm}$ in $\mathrm{CIP}_{\mathrm{HCl}}$, while it is shifted to higher ppm in $\mathrm{CIP}_{\mathrm{zw}}$ overlapping with $\mathrm{C} 4$ resonance at $178 \mathrm{ppm}$. This difference is consistent with the carboxyl group deprotonation in the zwitterionic form. The analysis of the intercalated samples, showing the same three groups of signals as those in the CIP salts, initially confirms the preservation of the CIP structural integrity upon intercalation into LDH. Marginal shifts in the positions can be observed probably due to the confinement of CIP into the LDH interlayer space. In particular, an upshift in the C3a resonance could be observed in all the samples from 168 to $172 \mathrm{ppm}$ as compared to $\mathrm{CIP}_{\mathrm{HCl}}$; this suggests the deprotonation of the carboxylic group, which is consistent with the intercalation of CIP in its anionic form. The splitting observed for the cyclopropane ring is due to the presence of other CIP entities since such splitting cannot be observed by nuclei couplings averaged by MAS. In the case of the $\mathrm{Zn}_{2} \mathrm{Al}-\mathrm{CIP}_{\mathrm{zw}} / \mathrm{HCl} @ 0.5$ samples, we can

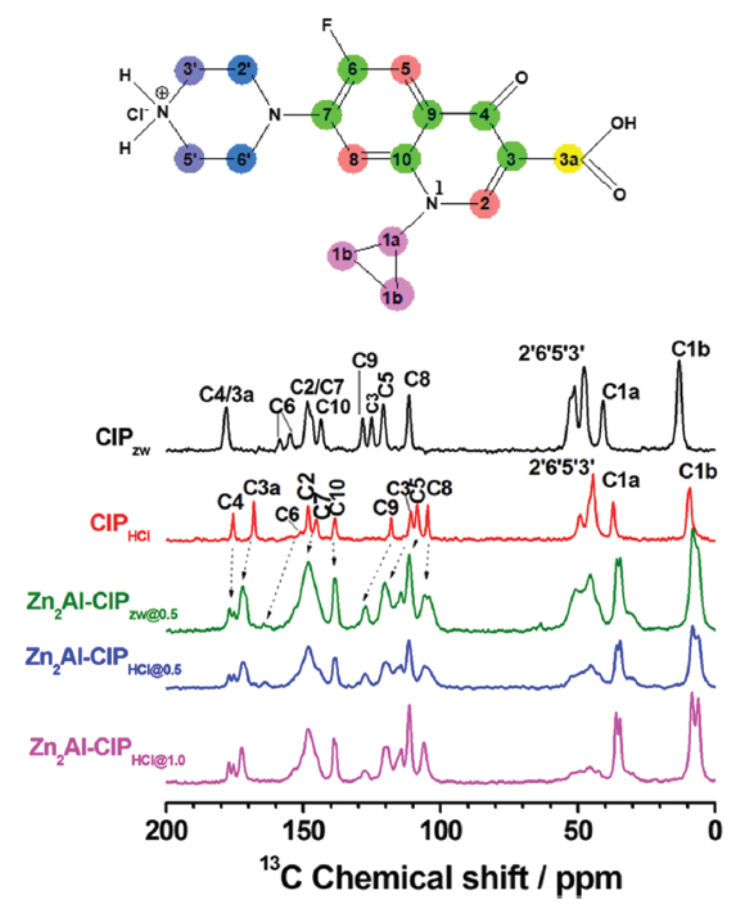

Fig. 5 Chemical structure of CIP showing the labels used to assign the ${ }^{13} \mathrm{C}$ CP MAS NMR spectra (top). The ${ }^{13} \mathrm{C}$ NMR spectra of CIP salts and $\mathrm{Zn}_{2} \mathrm{Al}-\mathrm{CIP}$-intercalated samples (bottom).

attribute this to the presence of residual free CIP, as evidenced from the XRD and chemical analysis data. In the case of the $\mathrm{Zn}_{2} \mathrm{Al}-\mathrm{CIP}_{\mathrm{HCl} @ 1.0}$ sample, the splitting can be ascribed to the presence of different environments for these carbon atoms related to the coexistence of both free and complex forms of CIP in the interlayer space. Both quinolone and piperazine moieties also undergo NMR peak broadening upon intercalation. Chemical shifts for CIP are averaged with the presence of $\pi$ electrons in the quinolone backbone. Moreover, the shift induced by the change in the electrostatic binding on C3a is effectively transmitted through the quinolone form because of its partly conjugated structure. The situation is different for the piperazine ${ }^{13} \mathrm{C}$ nuclei that exhibits $\sigma$ bonding. It is well known that the ${ }^{13} \mathrm{C}$ NMR peak profile (broadening) in the ${ }^{13} \mathrm{C}$ CPMAS 


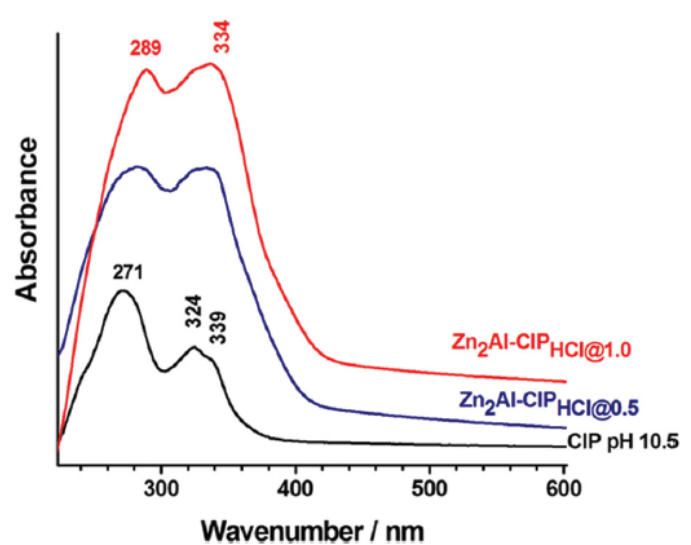

Fig. 6 UV-vis spectra of $\mathrm{Zn}_{2} \mathrm{Al}-\mathrm{ClP}_{\mathrm{HCl}}$ 1.0 and $\mathrm{Zn}_{2} \mathrm{Al}-\mathrm{CIP}_{\text {HCla0.5 }}$ as solid thin films and $1 \times 10^{-4} \mathrm{mg} \mathrm{mL}^{-1} \mathrm{CIP}_{\mathrm{HCl}}$ solution at $\mathrm{pH} 10.5$.

sequence is related to the efficiency of the magnetization transfer during the CP time. The relaxation profiles also depend on the molecular dynamics and associated relaxation dispersion of the longitudinal relaxation (spin-lattice) rate. Therefore, the fact that the signals of the piperazine ring overlap to form wide resonances in the intercalated samples can be explained by a higher degree of freedom of motion of the piperazine ring for $\mathrm{Zn}_{2} \mathrm{Al}$-CIP $\mathrm{HCl}$ 1.0, dangling in the $\mathrm{LDH}$ interlayer, as compared to the quinolone moieties closer to the layers.

The UV-vis absorption spectra of the $\mathrm{Zn}_{2} \mathrm{Al}-\mathrm{CIP}_{\mathrm{HCl} 1.0}$ and $\mathrm{Zn}_{2} \mathrm{Al}-\mathrm{CIP} \mathrm{HCl}_{\mathrm{HC} .5}$ samples are compared to those of the $\mathrm{CIP}_{\mathrm{HC}}$ solution at $\mathrm{pH}$ 10.5, as shown in Fig. 6. The absorption bands for CIP appear at $271 \mathrm{~nm}$ (band I) and 324/339 $\mathrm{nm}$ (band II) corresponding to the $\pi \rightarrow \pi^{*}$ and $n \rightarrow \pi^{*}$ transitions of the fluorobenzene moieties and quinolone ring, respectively. ${ }^{54,55}$ The $\mathrm{Zn}_{2} \mathrm{Al}-\mathrm{CIP} \mathrm{PCl}_{\mathrm{H} \text { 1.0 }}$ sample shows an obvious shift in the $\pi \rightarrow \pi^{*}$ transition to $289 \mathrm{~nm}$. Similar bathochromic shifts have already been reported for the complex formation of CIP with metal cations in an aqueous solution, ${ }^{11,56}$ thereby supporting the presence of the CIP-Al complex in the interlayer space of the $\mathrm{Zn}_{2} \mathrm{Al}-\mathrm{CIP}_{\mathrm{HCl}(1.0}$ sample.

\section{CIP release tests}

In vitro CIP release tests were performed with $\mathrm{Zn}_{2} \mathrm{Al}$ samples at $25{ }^{\circ} \mathrm{C}$ in simulated intestinal fluid at $\mathrm{pH} 7.5$ the using PBS medium. The drug release profiles, i.e., the percentage of CIP released into the PBS medium vs. time (Fig. 7a), show the differences between the $\mathrm{Zn}_{2} \mathrm{Al}-\mathrm{CIP}_{\mathrm{Zw} / \mathrm{HCl} @ 0.5}$ and $\mathrm{Zn}_{2} \mathrm{Al}-\mathrm{CIP} \mathrm{P}_{\mathrm{HCl} @ 1.0}$ samples. First, the release profiles indicate the occurrence of bursts in the case of $\mathrm{Zn}_{2} \mathrm{Al}-\mathrm{CIP}_{\mathrm{HCl}}$ 1.0 with about $70 \%$ of the CIP released after $1 \mathrm{~h}$, while the lower release of CIP was found with the $\mathrm{Zn}_{2} \mathrm{Al}-\mathrm{CIP} \mathrm{Zw}_{\mathrm{ZHCl} 0.5}$ samples with the release of $30 \%$ after $1 \mathrm{~h}$. Then, for $\mathrm{Zn}_{2} \mathrm{Al}-\mathrm{CIP}_{\mathrm{HCl}(\mathrm{1} .0}$, the release steeply increases, reaching $100 \%$ after $10 \mathrm{~h}$. On the other hand, the amounts of CIP released for the $\mathrm{Zn}_{2} \mathrm{Al}-\mathrm{CIP}_{\mathrm{zw} @ 0.5}$ and $\mathrm{Zn}_{2} \mathrm{Al}-\mathrm{CIP} \mathrm{HCl} @ 0.5$ samples reach a plateau in about $12 \mathrm{~h}$ at $50 \%$ and $60 \%$, respectively, and no longer change thereafter.

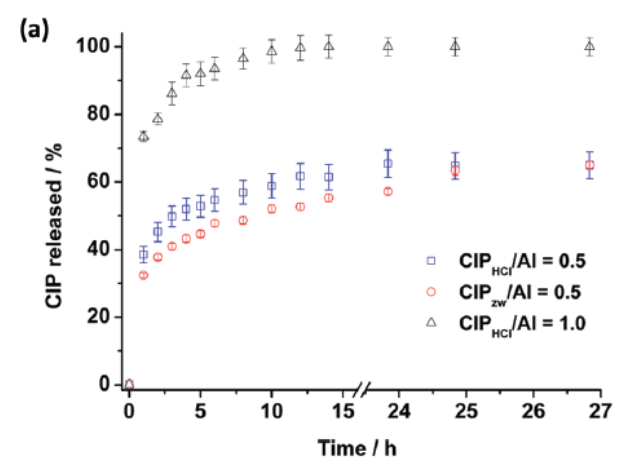

(b)

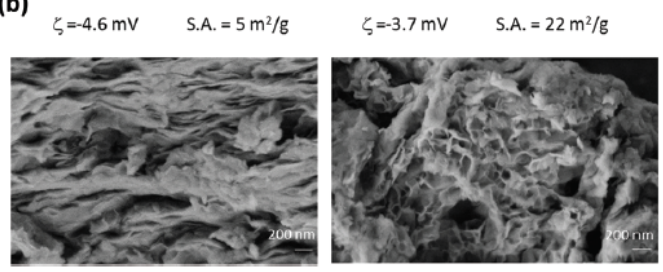

Fig. 7 (a) CIP cumulative release percentage (\%) profiles for the $\mathrm{Zn}_{2} \mathrm{Al}-\mathrm{CIP}$ samples performed in PBS at pH 7.50. (b) SEM images of $\mathrm{Zn}_{2} \mathrm{Al}-\mathrm{CIP} \mathrm{PCI}_{\mathrm{H} 1.0}$ (left) and $\mathrm{Zn}_{2} \mathrm{Al}-\mathrm{ClP}_{\mathrm{HCl}} \mathrm{e0.5}$ (right) with their zeta potential and surface area values.

It is well known that the kinetic release profiles of the drug from LDH systems in alkaline or neutral media involve an anionexchange mechanism. ${ }^{8}$ In the present case, the first stage of the release process can be attributed to the release of CIP drug that is weakly adsorbed on the surface of the particles and/or located on the external part (edges) of the structure. ${ }^{57-60}$ It should be noted that the presence of $3.5 \mathrm{wt} \%$ free CIP for $\mathrm{Zn}_{2} \mathrm{Al}-\mathrm{CIP}_{\mathrm{HCl}(0.5}$, as deduced from the chemical analysis (Table 1) and probably in the form of $\mathrm{CIP}_{\mathrm{HCl}}$ salt, is, therefore, relatively soluble at $\mathrm{pH}$ 7.5. This may explain the higher release rate observed for this sample as compared to the $\mathrm{Zn}_{2} \mathrm{Al}-\mathrm{CIP}_{\mathrm{Zw} @ 0.5}$ containing 5\% CIP that is probably less soluble in the form of $\mathrm{CIP}_{\mathrm{zw}}$ salt. The release in the second stage is dependent on the anion exchange between the interlayer CIP and phosphate species in the medium. The large interlayer distance in the case of $\mathrm{Zn}_{2} \mathrm{Al}-\mathrm{CIP}_{\mathrm{HCl}(1.0}$ facilitates the internal diffusion through the LDH particles and CIP anions can be completely exchanged/released. These results are comparable to those obtained by Xia et al. ${ }^{61}$ for a series of LDHhypertensive samples exhibiting different interlayer structures and release kinetics.

The XRD data of the samples recovered after a contact time of $24 \mathrm{~h}$ (Fig. ESI9, ESI $\dagger$ ) confirm the total release of the interlayer CIP anions in the case of the $\mathrm{Zn}_{2} \mathrm{Al}-\mathrm{CIP}_{\mathrm{HCl} \text { (a) } .0}$ sample with important changes for the $00 \mathrm{nl}$ reflections as a result of the exchange with the phosphate species. ${ }^{62}$ On the other hand, only a loss in crystallinity is observed for $\mathrm{Zn}_{2} \mathrm{Al}$-CIP $\mathrm{HCl} 0.5$ with no modification of the position of the $00 \mathrm{nl}$ reflections, indicating the presence of intercalated CIP. In both the cases, it is worth noting that the $110 / 113$ double peak is still visible, indicating a preservation of $\mathrm{LDH}$ layers after a contact time 
Table 2 Kinetic constants obtained for the CIP release from the LDH host in a PBS medium

\begin{tabular}{|c|c|c|c|c|}
\hline & \multicolumn{2}{|c|}{ Higuchi } & \multicolumn{2}{|c|}{ Korsmeyer-Peppas } \\
\hline & \multicolumn{2}{|c|}{$\frac{M_{t}}{M_{0}}=k \sqrt{ } t$} & \multicolumn{2}{|c|}{$\log \left(\frac{M_{t}}{M_{0}}\right)=\log$} \\
\hline & $R^{2}$ & $k\left(\% \mathrm{~h}^{-0.5}\right)$ & $R^{2}$ & $n$ \\
\hline $\mathrm{Zn}_{2} \mathrm{Al}-\mathrm{CIP} \mathrm{HCl}_{\mathrm{HC}}$ & 0.935 & 34.3 & 0.978 & 0.178 \\
\hline $\mathrm{Zn}_{2} \mathrm{Al}-\mathrm{CIP}_{\text {zw@0.5 }}$ & 0.970 & 26.6 & 0.982 & 0.185 \\
\hline $\mathrm{Zn}_{2} \mathrm{Al}-\mathrm{CIP} \mathrm{PCl}_{\mathrm{HCl} 1.0}$ & 0.982 & 68.1 & 0.963 & 0.139 \\
\hline
\end{tabular}

$R^{2}, M_{t}, M_{o}, t, k$, and $n$ are the correlation coefficient, amount of drug quantity released at time $t$, initial amount of the drug in the pharmaceutical formulation, release time, kinetic constant, and diffusional exponent, respectively. ${ }^{39}$

of $24 \mathrm{~h}$. The morphological characteristics of the samples are also informative, explaining the differences observed in the first step. All the samples display similar and slightly negative values of the zeta potential, $\zeta$, namely, $\sim-4.6 \mathrm{mV}$ for $\mathrm{Zn}_{2} \mathrm{Al}$ $\mathrm{CIP}_{\mathrm{HCl} @ 0.5}$ and $-3.7 \mathrm{mV}$ for $\mathrm{Zn}_{2} \mathrm{Al}-\mathrm{CIP}_{\mathrm{HCl} @ 1.0}$ related to the presence of CIP anions on the particle surfaces. On the other hand, the SEM images show the different agglomeration states of the crystallites (Fig. 7b), stacked in a more compact way in the case of $\mathrm{Zn}_{2} \mathrm{Al}$ $\mathrm{CIP}_{\mathrm{HCl} @ 1.0}$, resulting in a lower surface area of $5 \mathrm{~m}^{2} \mathrm{~g}^{-1}$ against the value of $22 \mathrm{~m}^{2} \mathrm{~g}^{-1}$ for $\mathrm{Zn}_{2} \mathrm{Al}$-CIP $\mathrm{HCl}_{\text {(0.5.5 }}$. This higher surface area for $\mathrm{Zn}_{2} \mathrm{Al}$-CIP $\mathrm{HCl} 0.5_{\text {. }}$ indicates that the external part of the particles is more exposed to the PBS medium and it is likely that only CIP anions located on the surface/edges of the particles participate in the release process measured for $\mathrm{Zn}_{2} \mathrm{Al}-\mathrm{CIP}_{\mathrm{HCl} @ 0.5}$, as shown in Fig. 7a.

Diffusion kinetic models can be applied to further investigate the CIP drug release process from the LDH carriers (Table 2 and Fig. ESI10, ESI $\dagger$ ). ${ }^{63-65}$ The importance of the process of diffusion in controlling the release rate of CIP was checked by applying the Higuchi model. This model fits fairly well with the release data for all the samples, and the calculated values of the rate constants indicate a much faster release for $\mathrm{Zn}_{2} \mathrm{Al}-\mathrm{CIP}_{\mathrm{HCl} @ 1.0}$ $\left(68.1 \% \mathrm{~h}^{-0.5}\right)$ than that for $\mathrm{Zn}_{2} \mathrm{Al}-\mathrm{CIP}$ HCl@0.5 $\left(34.3 \% \mathrm{~h}^{-0.5}\right)$. Interlayer diffusion takes a longer time than surface diffusion; CIP interparticle diffusion is the rate-limiting step of the release process and it is dependent on the interlayer distance. The application of the Korsmeyer-Peppas model also yielded good fits, confirming the diffusion mechanism. Furthermore, the calculated values of the diffusional exponent $n$ are less than 0.45 for all the samples, which means that the CIP release rate is controlled by diffusion from the interlayer of the particles via anion exchange.

\section{Discussion}

Based on the XRD analysis, along with the chemical, TGA IR, Raman, ${ }^{13} \mathrm{C}$ NMR, UV-vis, and HRTEM analyses data, the formation of two $\mathrm{Zn}_{2} \mathrm{Al}$-CIP-intercalated structures with very different interlayer distances of 21.2 and $32.1 \AA$ was observed. Similar results were obtained when using the $\mathrm{Mg}_{2} \mathrm{Al}$ LDH host, although the crystallinity of the samples was lower.

As mentioned earlier, there are only a few reports on the intercalation of CIP into LDH, but some of the published results are questionable. Silion et al. ${ }^{22}$ were the first to report the intercalation of CIP by the coprecipitation and ion-exchange methods in $\mathrm{Zn}_{2} \mathrm{Al} \mathrm{LDH}$ and obtained very close interlayer distances of 20.61 and $20.37 \AA$, respectively. Both these syntheses were carried out at pH 7.5, which corresponded to the zwitterionic form of CIP and not the anionic form. Moreover, the position of the $110 / 113$ double peak observed below $60^{\circ}$ ( $2 \theta$ with $\mathrm{Cu}-\mathrm{K} \alpha$ ) is actually not consistent with the formation of the LDH phase, but the LSH phase. Hesse et al. ${ }^{23}$ implanted ear prostheses coated with $\mathrm{Mg}_{2} \mathrm{Al}-\mathrm{SO}_{4} \mathrm{LDH}$ impregnated with CIP in white rabbits. Although no characterization of the impregnated LDH nanoparticles was provided, the study clearly showed the ability of this LDH/CIP physical mixture to combat local bacterial infections in the middle ear of rabbits. Similarly, Badar et al. ${ }^{24}$ investigated a physical mixture of CIP and $\mathrm{Mg}_{2} \mathrm{AlSO}_{4} \mathrm{LDH}$ deposited on porous titanium dises as coating implants: a prolonged drug release was observed in an infected mouse implant. Recently, Rezvani et al. ${ }^{25}$ reported the preparation of alginate/ $\mathrm{Zn}_{2} \mathrm{Al}-\mathrm{CIP}$ and chitosan/ $\mathrm{Zn}_{2} \mathrm{Al}$-CIP nanocomposites with $\mathrm{Zn}_{2} \mathrm{Al}$-CIP obtained by the coprecipitation method at $\mathrm{pH} 8.5$ followed by an ageing step at $70{ }^{\circ} \mathrm{C}$. An interlayer distance of $30.04 \AA$ was observed, which was comparable to the length of CIP, leading the authors to propose a bilayer arrangement. This interlayer is comparable to the value obtained for $\mathrm{Zn}_{2} \mathrm{Al}-\mathrm{CIP}_{\mathrm{HCl} 1.0}$; however, their XRD diffraction pattern is very different from that measured particularly with the relative intensities of successive $00 \mathrm{nl}$ diffraction peaks. Release studies carried out under different $\mathrm{pH}$ values by simulating the sequences in the gastrointestinal tract $(\mathrm{pH} \mathrm{1.2,} \mathrm{6.8,} \mathrm{and} \mathrm{7.4)}$ revealed a faster release rate $(92 \%)$ for CIP-LDH/alginate than that for CIP-LDH/chitosan (39\%). Finally, Mishra et al. ${ }^{66}$ reported the intercalation of a series of antibacterial agents, i.e., CIP, sulfanilamide, and oxazolidinone, into $\mathrm{Zn}_{2} \mathrm{Al} \mathrm{LDH}$ by the anionic exchange of sulfate anions at $\mathrm{pH} 10$ and $60^{\circ} \mathrm{C}$ in a water-ethanol solvent mixture. An interlayer distance of $20.7 \AA$ was reported as obtained from the position of the first peak at a lower angle on the XRD pattern; however, the positions of the subsequent peaks, which are assumed to be 00nl harmonics, are not consistent with the repetition of $d$-spacing.

Our results suggest the occurrence of parallel and competitive reactions of precipitation and complexation, which have not been observed in earlier studies. For the synthesis carried out for CIP/Al > 1, the formation of the LDH layer is prevented by the predominance of complexation reactions between CIP and the present metal cations. Indeed, CIP is known to form metal complexes at high $\mathrm{pH}$ values of the solution and the formation constant of CIP chelates decrease in the order of $\mathrm{Al}^{3+}>\mathrm{Fe}^{3+}>\mathrm{Cu}^{2+}>\mathrm{Zn}^{2+}>\mathrm{Mn}^{2+}>\mathrm{Mg}^{2+} \cdot{ }^{67}$ The CIP binding to $\mathrm{Al}^{3+}$ is stronger than that to other metals, and a substantial increase in the solubility of fluoroquinolones subsequent to complexation was reported. ${ }^{68}$ On the other hand, for CIP/Al less than or equal to 1 , the precipitation of the cations in their hydroxide forms is found to prevail, leading to the formation of an LDH phase intercalated with CIP in its anionic form. Finally, for $\mathrm{CIP} / \mathrm{Al}$ close to 1 , an interplay between the precipitation and complexation reactions would enable the cointercalation of CIP in its anionic form and $\mathrm{Al}^{3+}$ cations, leading to drug loading 


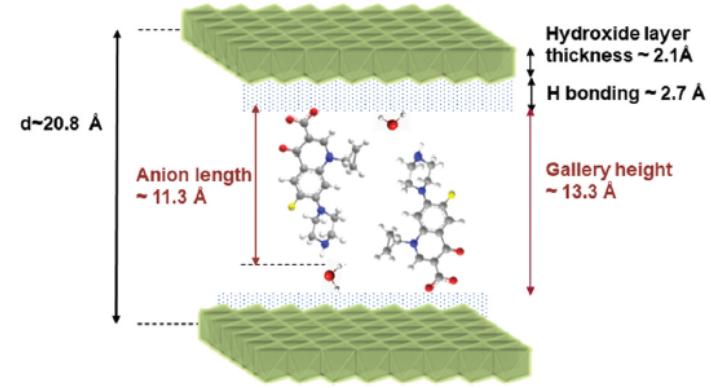

Fig. 8 Schematic arrangement of CIP anions in the interlayer space of $\mathrm{Zn}_{2} \mathrm{Al}-\mathrm{CIP}_{\mathrm{zw}(\mathrm{a} .5}$ and a representative of the structure of all the samples prepared with $\mathrm{CIP} / \mathrm{Al}=0.5$.

higher than that solely achievable by anion exchange. Interestingly, the amount of excess CIP and that of $\mathrm{Al}^{3+}$ correspond exactly to the reported ${ }^{53}$ stoichiometry of the aluminum CIP complex of $(\mathrm{HCl} \cdot \mathrm{CIP})_{3} \mathrm{Al}$, thereby suggesting the intercalation of both CIP anion and $(\mathrm{CIP})_{3} \mathrm{Al}$ complex in $\mathrm{Zn}_{2} \mathrm{Al}-\mathrm{CIP}_{\mathrm{HCl} 1.0}$ The presence of this complex is also supported by the UV-vis absorption measurements.

The full characterization done on the $\mathrm{Zn}_{2} \mathrm{Al}-\mathrm{CIP}_{\mathrm{zw} @ 0.5}$ and $\mathrm{Zn}_{2} \mathrm{Al}-\mathrm{CIP} \mathrm{HCl} @ 0.5$ samples did not show any differences in the features of intercalated CIP in its anionic form in both the cases. A similar $d$-spacing of about $21 \AA$ A was obtained probably resulting from a monolayer and interdigitated arrangement of the CIP anions, as reported by Latip et al. ${ }^{21}$ for layered zinc hydroxide (LZH) nitrate (Fig. 8).

In the case of $\mathrm{Zn}_{2} \mathrm{Al}$-CIP ${ }_{\mathrm{HCl}} @ 1.0$, the large number of $00 \mathrm{l}$ diffraction peaks (almost eleven are visible) allowed us to probe the structure of the interlayer space by the calculation of a onedimensional electron density map from the analysis of the integrated intensities of the $00 l$ peaks extracted from the above Le Bail profile decomposition and Fourier transformation. ${ }^{36}$ This approach has been successfully applied to the structural characterization of several intercalative nanohybrids. ${ }^{69}$ The resulting 1D plot is shown in Fig. 9a. The most intense peaks are due to the hydroxide layers containing elemental $\mathrm{Zn}$ and $\mathrm{Al}$. The carboxylate groups result in small maxima on the outer parts of the interlayer space at a distance of about $3.0 \AA$ from the inorganic layers, which is consistent with hydrogen bond interactions. The central minimum supports the bilayer arrangement with the CIP ions positioned on either side of the center. This minimum is framed by two small maxima attributable to the piperazine ring, and its distance from the carboxylate groups $(\sim 10.5 \AA)$ permits the slightly inclined orientation of the CIP species with respect to the hydroxide layers. The Patterson map was also calculated by considering all the integrated intensities extracted from the Le Bail fitting. As shown in Fig. 9, the electron density in the interlayer space of the $\mathrm{Zn}_{2} \mathrm{Al}-\mathrm{CIP}_{\mathrm{HCl}}$ 1.0 sample is fairly low; nonetheless, it shows distribution in different planes perpendicular to the $c$-stacking direction and the $z$-coordinates are consistent with the positions of the maxima noted on the 1D plot. The spreading of the density observed for each of these planes indicates the orientational disorder of the CIP ions. Water (a)

(b)

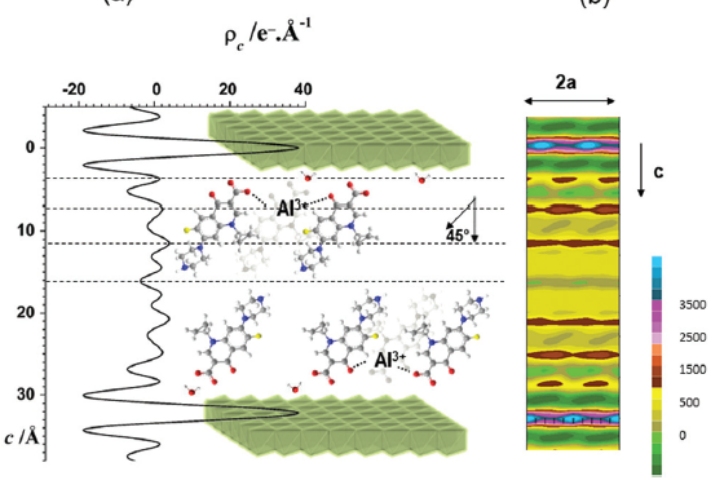

Fig. 9 Structural model for $\mathrm{Zn}_{2} \mathrm{Al}-\mathrm{CIP}_{\mathrm{HCl} 1 \mathrm{1} .0}$ deduced from (a) the onedimensional electron density projected along the $c$-stacking axis and (b) Patterson contoured map summed from 0 to 1 along the $b$-axis (the electron density scale shown on the right-hand side is in arbitrary units). Both were calculated from the profile refinement of the XRD data.

molecules are most certainly located near the LDH layer in the same plane as that of the carboxylate groups, forming hydrogen bonding with the $\mathrm{OH}$ groups of the LDH layers. The quasiabsence of electron density in the middle of the interlayer space confirms the bilayer arrangement. In addition, the observation of the pronounced local maxima on a plane located between the ketone group and carboxylate function may be attributed to the presence of heavy atoms, such as $\mathrm{Al}^{3+}$ cations. This location is consistent with the participation of these two groups in the coordination to aluminum, as that reported for the $(\mathrm{HCl} \cdot \mathrm{CIP})_{3} \mathrm{Al}$ complex. ${ }^{53}$

The intercalation of metal cations in the interlayer space of LDH via chelation with organic ligands, e.g., ethylenediaminetetraacetate (EDTA) or nitrilotriacetate (NTA), has already been reported. ${ }^{70}$ In some cases, complex formation leads to an excessively positive charge in the LDH, which is compensated by the intercalation of the additional anions present in the solution. On the other hand, LDH compounds belonging to the wermlandite group $^{71}$ have also shown the ability to intercalate hydrated cations such as $\mathrm{Na}^{+}, \mathrm{Ca}^{2+}$ and, more recently, $\mathrm{Li}^{+}$and $\mathrm{K}^{+}$in the presence of sulfate and carbonate anions. ${ }^{72}$

\section{Conclusions}

The intercalation of CIP, a broad-spectrum antibiotic, into the interlayer space of $\mathrm{Zn}_{2} \mathrm{Al}$ and $\mathrm{Mg}_{2} \mathrm{Al}-\mathrm{LDH}$ has been comprehensively investigated. By exercising tight control over the synthesis parameters, particularly the CIP/Al molar ratio, we identified the interplay between the coprecipitation and complexation reactions, leading to the formation of 2 different LDH-CIPintercalated structures with significantly different interlayer distances, namely, $\sim 21 \AA$ for $\mathrm{CIP} / \mathrm{Al}=0.5$ and $32 \AA$ for $\mathrm{CIP} / \mathrm{Al}=1.0$. A careful analysis of the data obtained from several characterization techniques, such as CHNS, ICP-AES, SEM-EDX for elemental analysis, TGA, IR-Raman, NMR, and UV-vis spectrometry, and HRTEM, as well as a detailed analysis of the XRD patterns 
(whole-pattern fitting and Fourier electron density map), allowed us to perform an accurate physicochemical and structural investigation of both these structures. Remarkably, the structure with the largest interlayer distance incorporated both CIP anions and $\mathrm{Al}(\mathrm{CIP})_{3}$ complex. This is a novel result and extremely interesting for drug delivery applications since it reveals the possibility to increase the CIP drug loading beyond the anionic-exchange capacity of LDH carriers. In vitro CIP release tests performed in simulated intestinal fluid indicated that the release rate was controlled by diffusion and dependent on the intercalated structure. A fast and complete CIP release could be achieved in less than $10 \mathrm{~h}$ by the anion-exchange mechanism for the structure with the largest interlayer distance, while only a surface reaction took place during the $24 \mathrm{~h}$ of the test for the other structure. The results obtained here can certainly be extended to other $\mathrm{LDH}$ compositions $\left(\mathrm{Ca}^{2+}, \mathrm{Cu}^{2+}, \mathrm{Fe}^{3+}\right.$, etc. $)$ associated to other CIP metal complexes.

\section{Conflicts of interest}

There are no conflicts to declare.

\section{Acknowledgements}

This work was supported by the Research Academic Cooperation Agreement CNRS/FAPESP-PRC project 1688 (France) and SPRINT-São Paulo Researchers in International Collaboration 2016/50317-9 (Brazil). Laboratório de Espectroscopia Molecular (LEM, Instituto de Química - USP) is acknowledged for the Raman spectra recording. Algerian Ministry of Higher Education and Scientific Research is acknowledged for the PhD fellowship (National Exceptional Program PNE 2018-2019).

\section{References}

1 L. Nicole, L. Rozes and C. Sanchez, Adv. Mater., 2010, 22, 3208 .

2 F. M. Fernandes, H. Baradari and C. Sanchez, Appl. Clay Sci., 2014, 100, 2.

3 D. Liu, F. Yang, F. Xiong and N. Gu, Theranostics, 2016, 6, 1306.

4 R. K. Kesrevani and A. K. Sharma, in Nanoarchitectured Biomaterials: Present Status and Future Prospects in Drug Delivery in Nanoarchitectonics for Smart Delivery and Drug Targeting, ed. A. M. Holban and A. M. Grumezescu, Elsevier, Amsterdam, 2016, pp. 35-56.

5 C. Taviot-Guého, V. Prévot, C. Forano, G. Renaudin, C. Mousty and F. Leroux, Adv. Funct. Mater., 2018, 28, 1703868.

6 M. Figueiredo, V. Cunha, F. Leroux, C. Taviot-Guého, M. Nakamae, Y. Kang, R. Souza, A. M. Martins, I. Koh and V. R. L. Constantino, ACS Omega, 2018, 3, 18263.

7 M. Rocha, P. Petersen, E. Teixeira-Neto, H. Petrilli, F. Leroux, C. Taviot-Guého and V. R. L. Constantino, RSC Adv., 2016, 6, 16419 .
8 V. Rives, M. del Arco and C. Martín, Appl. Clay Sci., 2014, 88-89, 239.

9 S. Saha, S. Ray, R. Acharya, T. K. Chatterjee and J. Chakraborty, Appl. Clay Sci., 2017, 135, 493.

10 D. Chimene, D. L. Alge and A. K. Gaharwar, Adv. Mater., 2015, 27, 7261 .

11 S. Muthumariappan, J. Pharm. Res., 2013, 6, 437.

12 M. Sohail, M. Khurshid, H. G. Saleem, H. Javed and A. A. Khan, Jundishapur J. Microbiol., 2015, 8, e19272.

13 N. Mandras, V. Tullio, P. M. Furneri, J. Roana, V. Allizond, D. Scalas and A. M. Cuffini, Antimicrob. Agents Chemother., 2016, 60, 1638.

14 D. Jain and R. J. Banerjee, J. Biomed. Mater. Res., Part B, $2007,86,105$.

15 M. Shah, Y. K. Agrawal, K. Garala and A. Ramkishan, Indian J. Pharm. Sci., 2012, 74, 434.

16 H. Khattar, S. Singh and R. S. R. Murthy, Int. J. Drug Delivery, 2012, 4, 316.

17 M. Shah and Y. Agrawal, J. Microencapsulation, 2012, 29, 331; M. Shah and Y. Agrawal, J. Dispersion Sci. Technol., 2013, $34,37$.

18 Q. Wu, Z. Li, K. Yin and L. Tie, Appl. Clay Sci., 2010, 50, 204. 19 A. Rivera, L. Valdés, J. Jiménez, I. Pérez, A. Lam, E. Altshuler, L. C. de Ménorval, J. O. Fossum, E. L. Hansen and Z. Rozynek, Appl. Clay Sci., 2016, 124, 150.

20 E. C. dos Santos, Z. Rozynek, E. L. Hansen, R. HartmannPetersen, R. N. Klitgaard, A. Løbner-Olesen, L. Michels, A. Mikkelsen, T. S. Plivelic, H. N. Bordallob and J. O. Fossuma, RSC Adv., 2017, 7, 26537.

21 A. F. A. Latip, M. Z. Hussein, J. Stanslas, C. C. Wong and R. Adnan, Chem. Cent. J., 2013, 7, 119.

22 M. Silion, M. I. Popa, G. Lisa and D. Hritcu, Rev. Roum. Chim., 2008, 53, 827.

23 D. Hesse, M. Badar, A. Bleich, A. Smoczek, S. Glage, M. Kieke, P. P. Müller, K.-H. Esser, M. Stieve and N. K. Prenzler, J. Mater. Sci.: Mater. Med., 2013, 24, 129.

24 M. Badar, M. I. Rahim, M. Kieke, T. Ebel, M. Rohde, H. Hauser, P. Behrens and P. P. Müller, J. Biomed. Mater. Res., Part A, 2015, 103, 2141.

25 Z. Rezvani and M. Shahbaei, Polym. Compos., 2015, 36, 1819-1825.

26 Z. Zeng, X. Tan, Y. Liu, S. Tian, G. Zeng, L. Jiang, S. Liu, J. Li, N. Liu and Z. Yin, Front. Chem., 2018, 6, 80.

27 F. Varanda, M. J. Pratas de Melo, A. I. Caço, R. Dohrn, F. A. Markrydaki, E. Voutsas, D. Tassios and I. M. Marrucho, Ind. Eng. Chem. Res., 2006, 45, 6386.

28 A. I. Caço, F. Varanda, M. J. Pratas de Melo, A. M. A. Dias and I. M. Marrucho, Ind. Eng. Chem. Res., 2008, 47, 8083.

29 R. Endermann, H. Labischinski, C. Ladel, U. Petersen and B. Newton, US 2004/0254194 A1, 2004.

30 P. J. McShane, J. G. Weers, T. E. Tarara, A. Haynes, P. Durbha, D. P. Miller, T. Mundry, E. Operschall and J. S. Elborn, Pulm. Pharmacol. Ther., 2018, 50, 72.

31 X. Li, F. Zhi and Y. Hu, Int. J. Pharm., 2007, 328, 177.

32 C. S. Fellati, A. A. Ahumada and R. H. Manzo, Acta Farm. Bonaerense, 1994, 13, 73. 
33 S. A. Breda, A. F. Jimenez-Kairuz, R. H. Manzoand and M. E. Olivera, Int. J. Pharm., 2009, 371, 106.

34 J. Rodriguez-Carvajal, Commission on Powder Diffraction (IUCr) Newsletter, 2001, vol. 26, pp. 12-19.

35 P. Thompson, D. E. Cox and J. B. Hastings, J. Appl. Crystallogr., 1986, 20, 79.

36 A. J. Jacobson and M. S. Whittingham, Intercalation Chemistry, Academic Press, New York, 1982, p. 67.

37 T. Roisnel and J. Rodriguez-Carvajal, in Proceedings of the Seventh European Powder Diffraction conference, Barcelona, May 20-23, 2000, ed. R. Delhez and E. J. Mitemeijer, Trans Tech Publications Inc., Switzerland, 2001, pp. 118-123.

38 B. Vaghela, R. Kayastha, N. Bhatt, N. Pathak and D. Rathod, J. Appl. Pharm. Sci., 2011, 1, 50.

39 M. L. Bruschi, in Mathematical Models of Drug Release in Strategies to Modify the Drug Release From Pharmaceutical Systems, ed. M. L. Bruschi, Woodhead Publishing, Elsevier, 2015, p. 63.

40 M. C. Lin, F. T. Chang and J. Y. Uan, J. Mater. Chem., 2010, 20, 6524 .

41 F. P. A. Fabbiani, B. Dittrich, A. J. Florence, T. Gelbrich, M. B. Hursthouse, W. F. Kuhs, N. Shankland and H. Sowa, CrystEngComm, 2009, 11, 1396.

42 I. Turel and A. Golobic, Anal. Sci., 2003, 19, 329.

43 D. G. Evans and R. C. T. Slade, in Structure and Bonding, ed. X. Duan and D. G. Evans, Springer-Verlag, Berlin Heidelberg, 2005, pp. 1-87.

44 A. L. Troutier-Thuilliez, C. Taviot-Guého, J. Cellier, H. HintzeBruening and F. Leroux, Prog. Org. Coat., 2009, 64, 182.

45 M. Pourbaix, Atlas of Electrochemical Equilibria in Aqueous Solutions, Pergamon Press, New York, 1966.

46 L. Desigaux, M. Ben Belkacem, P. Richard, J. Cellier, P. Léone, L. Cario, F. Leroux, C. Taviot-Guého and B. Bruno Pitard, Nano Lett., 2006, 6, 199.

47 C. Forano, U. Costantino, V. Prévot and C. Taviot-Gueho, in Handbook of Clay Science, ed. F. Bergaya and G. Lagaly, Elsevier, Amsterdam, 2013, 745-782.

48 M. Zupancic, R. C. Korosec and P. Bukovec, J. Therm. Anal. Calorim., 2001, 63, 787.

49 C. Guand and K. G. Karthikeyan, Environ. Sci. Technol., 2005, 39, 9166.

50 K. Nakamoto, Infrared and Raman Spectra of Inorganic and Coordination Compounds, Wiley-Interscience, New York, 1997.
51 U. Neugebauer, A. Szeghalmi, M. Schmitt, W. Kiefer, J. Poppa and U. Holzgrabe, Spectrochim. Acta, Part A, 2005, 61, 1505.

52 L. Mafra, S. M. Santos, R. Siegel, I. Alves, F. A. Almeida Paz, D. Dudenko and H. W. Spiess, J. Am. Chem. Soc., 2012, 134, 71.

53 A. K. Chattah, Y. G. Linck, G. A. Monti, P. R. Levstein, S. A. Breda, R. H. Manzo and M. E. Olivera, Magn. Reson. Chem., 2007, 45, 850 .

54 A. M. Khan and S. S. Shah, J. Dispersion Sci. Technol., 2009, 30, 1247.

55 M. Thakur, S. Pandey, A. Mewada, V. Patil, K. Monika, E. Goshi and M. Sharon, J. Drug Delivery, 2014, 2014, 282193.

56 M. Zupančič, I. Turel and P. Bukovec, Croat. Chem. Acta, 2001, 74, 61.

57 X. Bi, H. Zhang and L. Dou, Pharmaceutics, 2014, 6, 298.

58 D. Pan, H. Zhang, T. Zhang and X. Duan, Chem. Eng. Sci., 2010, 65, 3762 .

59 Z. Meng, X. Li, F. Lv, Q. Zhang, P. K. Chu and Y. Zhang, Colloids Surf., B, 2015, 135, 339

60 W. Huang, H. Zhang and D. Pan, AIChE J., 2011, 57, 1936.

61 S. J. Xia, Z. M. Ni, Q. Xu, B. X. Hu and J. Hu, J. Solid State Chem., 2008, 181, 2610.

62 U. Costantino, M. Casciola, L. Massinelli, M. Nocchetti and R. Vivani, Solid State Ionics, 1997, 97, 203.

63 J. M. Unagolla and A. C. Jayasuriya, Eur. J. Pharm. Sci., 2018, 114, 199.

64 P. L. Ritger and N. A. Peppas, J. Controlled Release, 1987, 5,37 .

65 Y. Gao, J. Zuo, N. Bou-Chacra, T. de Jesus, A. Pinto, S. D. Clas, R. B. Walker and R. Löbenberg, BioMed Res. Int., 2013, 2013, 136590.

66 G. Mishra, B. Dash, D. Sethi, S. Pandey and B. K. Mishra, Environ. Eng. Sci., 2017, 34, 1.

67 V. Uivarosi, Molecules, 2013, 18, 11153.

68 A. Serafin and A. Stanczak, Russ. J. Coord. Chem., 2009, 35, 81.

69 D. H. Park, J. H. Yang, A. Vinu, A. Elzatahry and J. H. Choy, Arabian J. Chem., 2016, 9, 190.

70 K. A. Tarasov, D. O'Hare and V. P. Isupov, Inorg. Chem., 2003, 42, 1919.

71 S. J. Mills, A. G. Christy, J. M. R. Genin, T. Kameda and F. Colombo, Mineral. Mag., 2012, 76, 1289.

72 A. R. Sotiles, L. M. Baika, M. TadeuGrassi and F. Wypych, J. Am. Chem. Soc., 2019, 141, 531. 